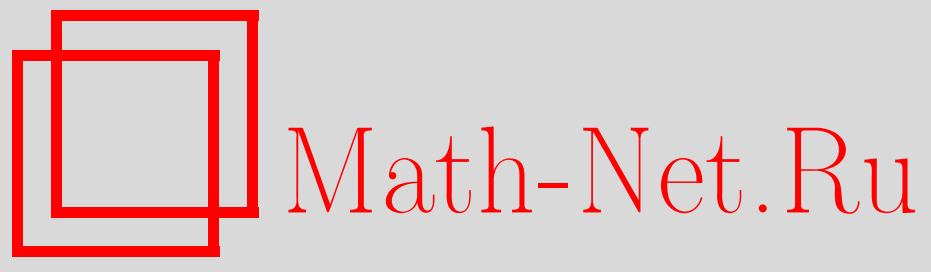

А. М. Вершик, С. В. Востоков, О праздновании 300летия со дня рождения Леонарда Эйлера, УМН, 2007, том 62, выпуск 4, 186-189

DOI: https://doi.org/10.4213/rm7923

Использование Общероссийского математического портала Math-Net.Ru подразумевает, что вы прочитали и согласны с пользовательским соглашением http://www . mathnet.ru/rus/agreement

Параметры загрузки:

IP: 35.173 .137 .237

26 апреля 2023 г., 18:16:21

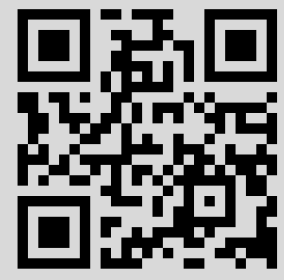




\section{О праздновании 300-летия со дня рождения Леонарда Эйлера}

В 2007 г. исполнилось 300 лет со дня рождения великого ученого - Леонарда Эйлера (15.IV.1707-18.IX.1783). Эйлер был ученым универсального типа; масштаб его дарования и его роль в науке - подобны масштабу и роли основоположников современной науки - Леонардо да Винчи, И. Ньютона, Г. В. Лейбница. Широта его интересов и результаты его разнообразной деятельности, пожалуй, не имели себе равных - он был архитектором (расчет по чертежам Эйлера моста Кулибина), географом (первый Атлас Российской Империи составлялся при активном участии Эйлера), философом, написавшим незабываемые "Письма к немецкой принцессе"; ему принадлежит, по-видимому, первая в истории теория музыки; он занимался военным делом (баллистика), мореплаванием (навигация), астрономией, гидравликой и др. Но, конечно, главные достижения Эйлера лежат в области математики, механики и физики. Невозможно представить себе, сколь значительно влияние работ Эйлера на последующее развитие этих наук.

Родившись в швейцарском городе Базеле в 1707 г., он оставался всю жизнь швейцарским подданным, поэтому не только Россия, но и Швейцария справедливо считает Эйлера своим ученым. Однако, покинув Базель в двадцатилетнем возрасте, он так ни разу и не побывал на родине. Судьба распорядилась так, что, не получив места работы в Базеле, Эйлер - начинающий талантливый ученый - поехал в 1727 г. в Россию, по рекомендации своего учителя Иоганна Бернулли и по приглашению Российской академии наук. Здесь он сразу стал одной из ключевых фигур в только что созданной Российской академии наук. Это оказалось счастьем и для России, и для Эйлера. Он стал без преувеличения вместе с Ломоносовым основателем зарождавшейся тогда Российской науки. Известность Л. Эйлера и его трудов в научном мире восемнадцатого века и, разумеется, в последующие десятилетия превосходила известность всех остальных ученых. Он был иностранным членом академий всех стран, где наука существовала, и даже только что образованной Американской академии наук.

По различным оценкам Эйлеру принадлежит более 800 названий научных работ, статей, книг, при этом прижизненных публикаций около 500; издание и переиздание его опубликованных и неопубликованных работ растянулось на столетия и еще не завершено; полное собрание сочинений рассчитано более чем на 70 томов. Эйлер считается едва ли не самым плодовитым математиком всех времен. Его рукописи хранятся в Библиотеке РАН в С.-Петербурге, работа над ними далеко не закончена; недавно появилась интересная, но несколько неопределенная идея выложить все тексты в Интернете.

K сожалению, организовать научную школу и воспитать достаточное число прямых учеников Л. Эйлеру не удалось, ведь в то время в С.-Петербурге еще не функционировал в полном смысле слова университет; однако, как справедливо заметил Ж.-Л. Лагранж, "все мы - ученики Эйлера". 
В 1741 г., когда в России началось очередное смутное время, Эйлер откликнулся на приглашение Фридриха Великого поехать в Берлин, здесь он проработал более двадцати лет. Поэтому и Германия также имеет все основания считать его немецким математиком. Позже, в 1766 г., его с большими почестями вернула в Россию Екатерина Великая, и он остался в Петербурге, продолжая активно работать до своей кончины в 1783 г., когда по выражению историка математики М. Кондорсе “Эйлер перестал жить и вычислять". Возможно, Эйлер - одна из первых фигур ученого, имя которого принадлежит сразу нескольким странам; и в первую очередь - Науке.

Эйлер прожил жизнь кабинетного ученого, но разнообразные события, подчас сильно затруднявшие его жизнь, преследовали его. Усадьбу Эйлера под Берлином сожгли и разграбили казаки, занявшие город во время Семилетней войны с Пруссией, правда, Елизавета Петровна возместила ущерб. Уже в преклонном возрасте его, слепого, в последнюю минуту вытащил из горящего дома в Петербурге слуга-швейцарец. В 1735 г. он потерял один глаз, а в 1766 - второй; для математика слепота столь же тяжела, как для музыканта глухота. Можно лишь восхищаться жизненным подвигом Эйлера-ученого. Последние годы его жизни в работе ему помогал сын (один из 13 детей Эйлера) - математик Иоганн Эйлер (1734-1800).

Феноменальная память, быстрота вычислений, математическое чутье и интуиция, широта кругозора и при всем том необъяснимая продуктивность - вот черты Эйлера-математика. Каждый из нас может назвать с десяток формул, теорем, правил Эйлера. Но на самом деле он автор многих понятий, которые по тем или иным причинам приписаны другим ученым, вот лишь два примера: дзета-функция Римана, гипергеометрический ряд Гаусса - это изобретения Эйлера. XVII-XVIII века были эпохой становления главных понятий и принципов современной науки, поэтому вопросы обоснования концепций, строгости доказательств и т. д. не были в повестке дня; претензии к некоторым рассуждениям Эйлера, состоящие в том, что они необоснованны или неполны, - неуместны. Например, формула для эйлеровой характеристики (известная в частном случае еще Декарту) была им доказана лишь для сферы, но уже само ее открытие было началом современной топологии.

Имя Эйлера упоминается во всех разделах современной математики: теории чисел, топологии, алгебраической геометрии, комбинаторике, анализе, теории обыкновенных дифференциальных уравнений и динамических систем, гидродинамике, механике, теории упругости и др. Он был замечательным педагогом своего времени, написавшим несколько учебников для начинающих.

Поскольку основную часть своей жизни Леонард Эйлер провел в России, естественно, что и центр празднования юбилея был здесь, в С.-Петербурге. Мы считаем Леонарда Эйлера петербургским и российским ученым; его имя носит международный математический институт в С.-Петербурге. Но подготовка к празднованию 300-летия со дня рождения Эйлера началась задолго до юбилея в нескольких странах. Швейцария готовилась к этому событию особенно тщательно - были выпущены красочные плакаты с текстами, понятными школьнику, и даже комиксы (“Кто такой Эйлер?", “Почему летают самолеты?" и т. д.). На родине Эйлера, в Базеле, состоялась торжественная сессия. Во Франции была научная конференция, посвященная 250-летию гидродинамического уравнения Эйлера. Лекции и заседания прошли в Германии, в Австрии. К сожалению, разумная и вполне осуществимая идея об объявлении 2007 года годом Эйлера по программе ЮНЕСКО несколько запоздала, и этого сделать не удалось. 
Наиболее существенным шагом в подготовке юбилея Эйлера в С.-Петербурге стала организация Фонда Эйлера. Учредителями Фонда стали Л. Д. Фаддеев, И. А. Ибрагимов, А. М. Вершик, С. В. Востоков; последний, самый молодой из них, стал Президентом фонда (см. www.euler-foundation.org). О работе фонда и об организованном фондом конкурсе им. Эйлера см. отдельную заметку в этом выпуске журнала и упомянутую страницу в Интернете. Российской академии наук удалось убедить администрацию принять постановление о праздновании юбилея (Постановление Правительства Российской Федерации № 1304-р от 16.09.2006). Но еще до этого фонд Эйлера ходатайствовал о принятии постановления Правительства С.-Петербурга об этом праздновании. Такое постановление было принято (июнь 2006 г.), и именно благодаря этому удалось внести в бюджет города статью расходов на проведение юбилея.

В планах подготовки юбилея были выпуск юбилейных марки и монеты, переименование одной из улиц в улицу Эйлера, приведение в порядок могилы Л. Эйлера, установка памятника и др. При некоторой поддержке правительства С.-Петербурга удалось выпустить конверт с портретом Эйлера (конверт выпустили в Москве, фонд оплатил юбилейное гашение марки во время эйлеровского фестиваля) и привести в надлежащий вид могилу в Александро-Невской лавре. Была приведена в порядок памятная доска на доме, где жил в последние годы Эйлер.

На деньги спонсоров был спроектирован и выполнен памятник Эйлеру (автор скульптор А.Г. Дёма), он был установлен возле входа в Международный Институт Эйлера в С.-Петербурге.

При активном участии Фонда Эйлера студия режиссера И. Шадхана сняла интересный документальный фильм “Об Эйлере” с многочисленными интервью с учеными, беседами со школьниками, учителями и др. Однако сделать удалось не все. Попытка увековечить память Эйлера в топонимике С.-Петербурга города не увенчалась успехом. Чиновником был предложен неприемлемый вариант - назвать именем Эйлера некий безымянный переулок в Старом Петергофе около университета. Имелось также в виду идея дать имя Эйлера какой-либо школе.

Фонд Эйлера принял самое активное участие в подготовке и проведении Конгресса Эйлера. По замыслу организаторов юбилея конгресс состоял из трехдневного фестиваля и серии сателлитных конференций. Далее мы приводим информацию о эйлеровском конгрессе и связанных событиях.

\section{Международный математический конгресс, посвященный 300-летию со дня рождения Леонарда Эйлера}

Конгресс включал в себя Эйлеровский Фестиваль (10-12 июня) и серию конференций по различным областям математики, механики и физики. Кроме того, сюда же можно присоеднить историко-научную конференцию "Эйлер и современная наука", которая состоялась 14-16 мая; заседание Исполнительного комитета Европейского математического общества в институте Эйлера (8-9 июня) и визит в С.-Петербург делегации Американской ассоциации учителей, приуроченный к эйлеровскому юбилею (середина июля).

В локальный оргкомитет конгресса входили: Ю. Д. Бураго, А. М. Вершик, С. В. Востоков, В. А. Гриценко, П. Г. Зограф, И. А. Ибрагимов, С. В. Кисляков, Г. А. Леонов, Ю. В. Матиясевич, Г. А. Серёгин, Э. А. Тропп, Л. Д. Фаддеев.

Фестиваль стал кульминацией конгресса. В первый день Фестиваля (10 июня) после торжественного открытия состоялось вручение Золотой медали им. Л. Эйлера РАН акад. В.В. Козлову, а затем вручение премий победителям конкурса фонда 
Эйлера. Пленарные доклады первого дня: “Эйлер и современная наука", J. Bruning (Humboldt University, Berlin); “Эйлер в С.-Петербурге”, В. В. Козлов (Математический институт им. В. А. Стеклова, Москва).

11 июня состоялось торжественное открытие бюста Л. Эйлеру в Институте Эйлера и посещение его могилы в Александро-Невской лавре, затем пресс-конференция и торжественный прием.

Конгресс включал в себя серию из 9 конференций:

1. Л. Эйлер и современная комбинаторика.

2. Уравнения Эйлера и смежные проблемы.

3. Арифметическая геометрия.

4. Геометрическая конференция (объединенная с празднованием девяностопятилетия А. Д. Александрова).

5. 16-я конференция по математическому анализу.

6. Модулярные формы и модульные пространства.

7. Аналитические методы небесной механики.

8. Теоретическая и математическая физика.

9. Методы математического моделирования.

Подробности имеются на сайте: http://www.pdmi.ras.ru/EIMI/2007/Euler300/

A. М. Вериик, С.В. Востоков 